\title{
Soil Productivity Index in the Selected Area of Post-Mining Geomechanical Deformations
}

\author{
Sławomir Klatka ${ }^{1}$ \\ 1 Department of Land Reclamation and Environmental Development, University of Agriculture in Krakow, \\ Al. Mickiewicza 24/28, 31-059 Kraków, Poland \\ e-mail: slawomir.klatka@urk.edu.pl
}

\begin{abstract}
Geomechanical and hydrological surface deformation caused by the underground hard coal extraction leads to limited agricultural and natural soil use. The paper presents results of soil productivity indices determined in the area of post-mining subsidence depression near Libiąż. The algorithm of method suggested by Zhengi Hu et al. [1992] was used for the computations. The obtained results of field and laboratory analyses indicate soils degradation due to water logging and a necessity to undertake reclamation measures to restore their previous values. Determined productivity indices (PI) characterise the selected ground as the area with poor conditions for agricultural production. The reason for low PI values is a change in the soil properties because of degradation. The methods presented in the paper may be used to determine the degree of soil degradation in the areas of hard coal mining.
\end{abstract}

Keywords: hard coal mining, soil degradation, soil productivity index

\section{INTRODUCTION}

In the areas intensively exploited by industry, such as hard coal mining regions, almost all elements of the natural environment undergo degradation [Zając and Zarzycki 2013]. The processes occurring in the orogens and on the surface caused by the underground hard coal extraction lead immediately to subsidence and the area deformation making cultivation difficult or eliminating natural soil use [Klatka et al. 2016]. The phenomenon also causes hydrological soil degradation, such as drainage or water logging [Kaszowska 2007]. A high level of soil dampness worsens the conditions for plant vegetation and intensifies expansion of hydrophilous plants, which causes soils degradation, lowering their productivity and forces a change of the soil use [Rosik-Dulewska et al. 1999]. Quality of the soil environment in post-mining areas may be determined on the basis of soil quality classes, agricultural suitability complexes and crop yields [Reith and Charles 1982]. A more precise assessment result may be obtained taking into consideration many other elements, such as soil properties and form and kind of surface degradation [Porter et al. 1988]. Complexity of the issue of environmental conditions assessment for the needs of reclamation has been reflected in the quantity and diversity of applied methods [Klatka et al. 2016]. One of these is the soil productivity index method developed by Zhengi Hu et al. [1992], which makes possible precise determining present quality of soils degraded by mining.

Determining soil properties and productivity indices in the post-mining areas may be also used to assess the effects of conducted reclamation [Doll et al. 1984].

The aim of the paper was determining productivity indices for the soils undergoing degradation in the area of selected subsidence depression caused by hard coal extraction.

\section{MATERIALS AND METHODS}

The research was conducted in the hard coal post-mining area of 6.73 ha localised near Libiąż town. Geomechanical deformations of the surface caused formation of a flogged area 
and hydrological soil degradation as water logging. Currently in this area, there are energy infrastructure and unpreserved drainage ditches overgrown with vegetation. The terrain is used as wet meadows and pastures, in some parts marshy. In order to characterise soil properties and assess the degree of their degradation, 4 soil openings were made with the description of geomorphological features and material for analyses was collected. Detailed location of the pits was presented in Figure 1.

The properties of collected soils were analysed in a laboratory by means of standard method applied in soil science. The granulometric composition was determined using Casagrande's method in Prószyński's modification. Granulometric groups and sub-groups were established basing on Polish standard PN-R04033. Physical properties (bulk density and total porosity) were determined using method of Kopecky's cylinders of $100 \mathrm{~cm}^{-3}$ volume [Mocek et al. 1997]. Specific gravity was determined by pictometry in distilled water. The soil $\mathrm{pH}$ was measured by potentiometer in $\mathrm{H}_{2} \mathrm{O}$ and $1 \mathrm{n} \mathrm{KCL}$, whereas electrolytic conductivity was measured by conductometer in soil solutions at
1:2.5 soil:water ratio. Organic matter content was determined by Tiurin's method in Oleksynowa's modification [Oleksynowa et al. 1987], which relays on humus oxidation by potassium dichromate $\left(\mathrm{Cr}^{6+}\right)$. Saturated conductivity coefficient were determined in laboratory by means of pressure drop method in the apparatus basing on Darcy's law with regulated water pressure height and electronic reading of water volume. Saturated conductivity coefficient using this apparatus is based on linear relationship between flow and hydraulic gradient at so called laminar flow, according to Darcy's law [Baver at al. 1972, Ryczek at al. 2017]. The investigation results were shown in Table 1. Productivity index (PI) was calculated on the basis of Zhengi $\mathrm{Hu}$ et al. [1992] method. The essence of the method is based on the equation fixing the relationships between productivity index and physical, chemical and physical-water soil properties. The basis of soil productivity index is an equation correlating the productivity index with soil properties, developed by Neill [1979].

The main element of the method may take into consideration the following soil properties: soil granulometric composition, bulk density,

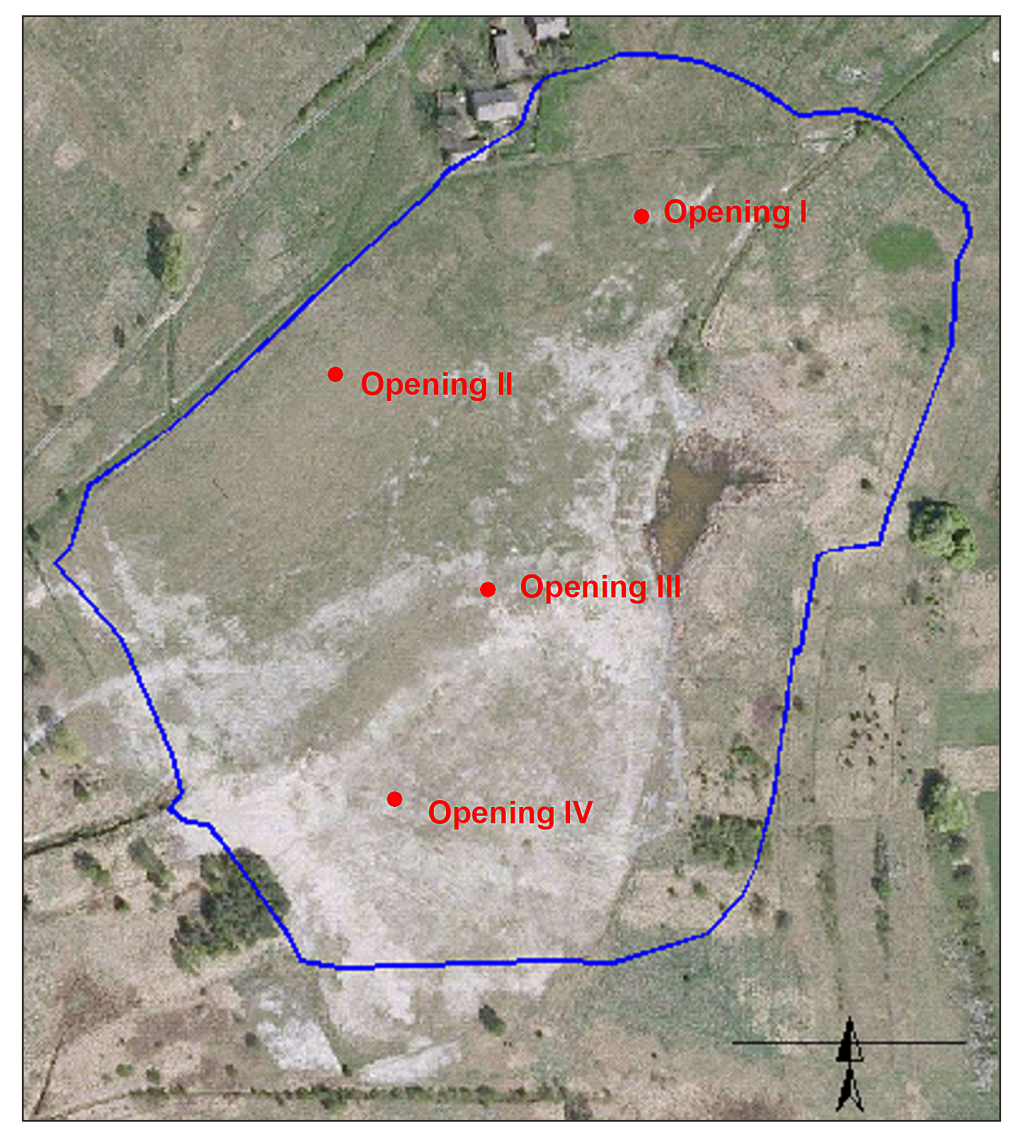

Fig. 1. Location of soil openings 


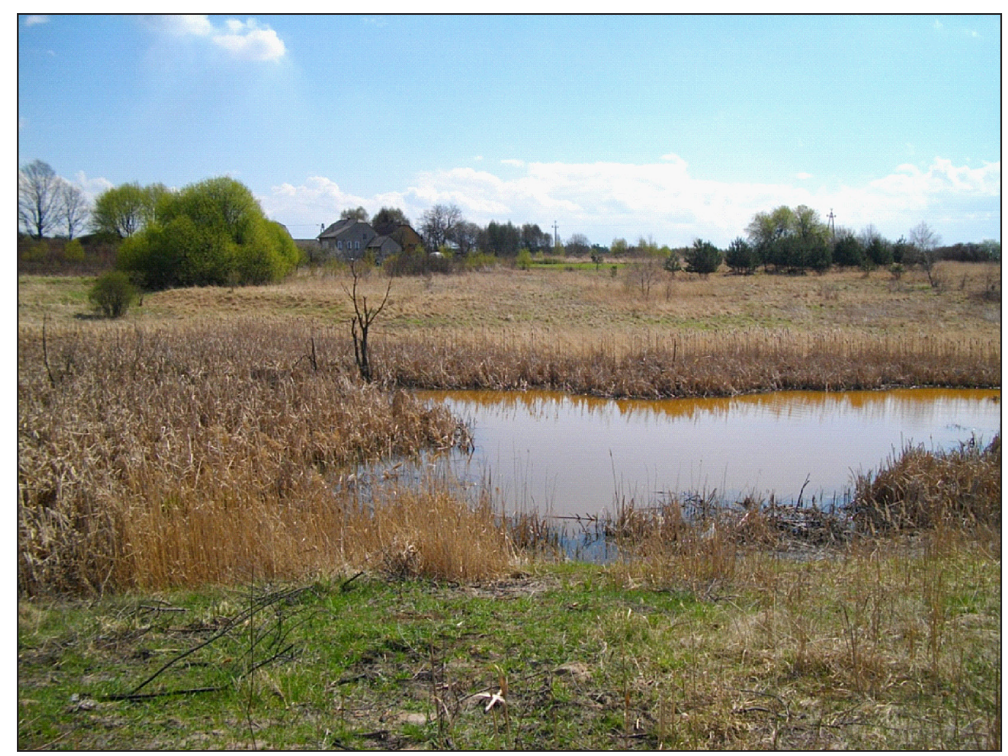

Fig 2. View of the study area

specific gravity, compactness, saturated conductivity coefficient, porosity, soil $\mathrm{pH}$, organic matter content, electrolytic conductivity, depth of the root zone, aggregate stability and sodium content. Computations of PI may include all above mentioned soil parameters or only several selected ones. The productivity index may be determined on the basis of the equation:

$$
P I=\sum_{i=1}^{n}\left(w_{i} \times r_{i}\right)
$$

where: $P I-$ soil productivity index

$n$ - number of parameter (soil property) $w_{i}$ - weighting factor for a given parameter (soil property), however

$$
\sum_{i=1}^{n} w_{i}=1
$$

where: $r_{i}$ - coefficient $(0-1)$ for the i-th soil parameter in case of a homogenous soil profile.

If a soil profile is composed of many horizons or layers, $r_{i}$ coefficient is calculated from the formula:

$$
r_{i}=\sum_{j=1}^{L_{i}}\left(R L_{i j} \times W L_{j}\right)
$$

where: $R L_{i j}$ - functional coefficient determined on the basis of tabular data (0-1) and the $\mathrm{i}$-th parameter (soil property) in the $\mathrm{j}$-th horizon or soil layer,

$W L_{j-}$ weighting factor for the $\mathrm{j}$-th level, whereby:

$$
\sum_{j=1}^{m} W L_{j}=1
$$

where: $L j-$ number of a subsequent horizon in a soil profile,

$m$ - number of horizons.

Calculations of PI index were conducted by means of the Author's original software, whose graphic algorithm was presented in Figure 3. Input data for the computations were determined properties of the soil material collected from the prepared soil pits. Weighting factors for the soil properties were assumed on the same level $w_{i}=0.09$, whereas weighting factors for the soil profile horizons $W L_{j}=0.33$. The results of calculations were presented in Table 1.

\section{RESULTS AND DISCUSSION}

According to Polish Soil Classification [PTG 2011], investigated soils belong to the order of brown earths, eutrophic brown soils type and gleyic eutrophic brown soils sub-type. These soils reveal properties of brown earths, but differ from them with a higher moisture content in the profile. Analysis of the laboratory analyses results shows that sandy loams and loamy sands prevail in the investigated area. The soils with such mechanical composition are regarded as not very resistant to degradation processes caused by hard coal extraction [Klatka et al. 2019]. Specific gravity was between 2.48 and $2.65 \mathrm{~g} \cdot \mathrm{m}^{-3}$ (on average 
Table 1. Properties and productivity index of investigated soils

\begin{tabular}{|c|c|c|c|c|c|c|c|c|c|c|c|c|}
\hline \multirow{3}{*}{ Soil properties } & \multicolumn{3}{|c|}{ Opening I } & \multicolumn{3}{|c|}{ Opening II } & \multicolumn{3}{|c|}{ Opening III } & \multicolumn{3}{|c|}{ Opening IV } \\
\hline & \multicolumn{12}{|c|}{ Layer [cm] } \\
\hline & $0-28$ & $29-84$ & $85-135$ & $0-32$ & $33-89$ & $90-118$ & $0-30$ & $31-59$ & $60-102$ & $0-28$ & $29-75$ & $76-150$ \\
\hline $\begin{array}{l}\text { Sand fraction } \\
\text { content }(2- \\
0.05 \mathrm{~mm})[\%]\end{array}$ & 74 & 68 & 72 & 72 & 81 & 82 & 68 & 67 & 71 & 83 & 79 & 67 \\
\hline $\begin{array}{l}\text { Silt fraction content } \\
(0.05-0.002 \mathrm{~mm}) \\
{[\%]}\end{array}$ & 22 & 21 & 18 & 24 & 10 & 8 & 17 & 26 & 22 & 9 & 12 & 23 \\
\hline $\begin{array}{l}\text { Lay fraction content } \\
(<0.002 \mathrm{~mm})[\%]\end{array}$ & 4 & 11 & 10 & 4 & 9 & 10 & 15 & 7 & 7 & 8 & 9 & 10 \\
\hline Soil texture & $\mathrm{pg}$ & gp & gp & gp & $\mathrm{gp}$ & $\mathrm{pg}$ & gp & $\mathrm{gp}$ & $\mathrm{gp}$ & $\mathrm{pg}$ & $\mathrm{pg}$ & $\mathrm{gp}$ \\
\hline $\begin{array}{l}\text { Specific gravity } \\
{\left[\mathrm{Mg} \cdot \mathrm{m}^{-3}\right]}\end{array}$ & 2.48 & 2.61 & 2.64 & 2.58 & 2.59 & 2.65 & 2.59 & 2.62 & 2.65 & 2.60 & 2.65 & 2.62 \\
\hline $\begin{array}{l}\text { Bulk density } \\
{\left[\mathrm{Mg} \cdot \mathrm{m}^{-3}\right]}\end{array}$ & 1.42 & 1.54 & 1.57 & 1.41 & 1.52 & 1.57 & 1.42 & 1.54 & 1.57 & 1.41 & 1.52 & 1.57 \\
\hline Porosity [\%] & 48.54 & 45.65 & 38.25 & 46.25 & 39.25 & 41.22 & 45.18 & 42.75 & 41.54 & 44.77 & 42.75 & 40.30 \\
\hline Reaction in $\mathrm{KCl}$ & 6.55 & 6.25 & 6.44 & 6.78 & 6.55 & 6.48 & 6.62 & 6.83 & 6.86 & 6.15 & 6.29 & 6.33 \\
\hline Reaction in $\mathrm{H}_{2} \mathrm{O}$ & 6.97 & 7.02 & 6.48 & 6.87 & 6.87 & 6.51 & 7.12 & 6.42 & 6.43 & 6.24 & 6.50 & 6.75 \\
\hline $\begin{array}{l}\text { Electrolitic } \\
\text { conductivity } \\
{\left[\mathrm{mS} \cdot \mathrm{cm}^{-1}\right]}\end{array}$ & 0.20 & 0.16 & 0.08 & 0.12 & 0.10 & 0.09 & 0.13 & 0.14 & 0.06 & 0.07 & 0.08 & 0.11 \\
\hline $\begin{array}{l}\text { Organic matter } \\
\text { content [\%] }\end{array}$ & 3.56 & - & - & 3.84 & - & - & 5.76 & - & - & 4.09 & - & - \\
\hline $\begin{array}{l}\text { Saturated } \\
\text { conductivity } \\
\text { coefficient }\left[\mathrm{m} \cdot \mathrm{d}^{-1}\right]\end{array}$ & 0.00064 & 0.00084 & 0.00125 & 0.00125 & 0.0235 & 0.01287 & 0.00326 & 0.00260 & 0.000151 & 0.001251 & 0.000265 & 0.005824 \\
\hline Productivity index & & 0.54 & & & 0.61 & & & 0.59 & & & 0.64 & \\
\hline
\end{tabular}

$2.60 \mathrm{~g} \cdot \mathrm{m}^{-3}$ ) and was approximate to the values most frequently occurring in the soils of Poland [Mocek 2015]. Values of bulk density were on average of $1.50 \mathrm{~g} \cdot \mathrm{m}^{-3}$ and also approximated medium values noted for the soils, which according to Assouline at al. [1997] range between $0.75-1.90 \mathrm{~g} \cdot \mathrm{m}^{-3}$. The lowest values of bulk density were registered in the soil humus horizons. In lower horizons these values were increasing with growing soil compactness and degree of waterlogging in the soil profiles. The imminent consequence of the changes in soil compactness due to increased moisture content are changes of total porosity and distribution of soil pores [Baranowski 1980]. Total porosity ranged from 38.25 to $48.54 \%$, on average $43.09 \%$. Bulk density and total porosity affect shaping of main agrotechnical values in soils, as well as their air and water

\begin{tabular}{|c|c|c|c|}
\cline { 2 - 4 } \multicolumn{1}{c|}{} & $w_{1}$ & $w_{2}$ & $w_{3}$ \\
\cline { 2 - 4 } \multicolumn{1}{c|}{} & $i=1$ & $i=2$ & $i=3$ \\
\hline$W L_{1}$ & $\mu_{1,1}$ & $\mu_{1,2}$ & $\mu_{1,3}$ \\
\hline$W L_{2}$ & $\mu_{2,1}$ & $\mu_{2,2}$ & $\mu_{2,3}$ \\
\hline$W L_{3}$ & $\mu_{3,1}$ & $\mu_{3,2}$ & $\mu_{3,3}$ \\
\hline
\end{tabular}

\begin{tabular}{|c|}
\hline$w_{n}$ \\
\hline$i=n$ \\
\hline$\mu_{1, n}$ \\
\hline$\mu_{2, n}$ \\
\hline$\mu_{3, n}$ \\
\hline
\end{tabular}
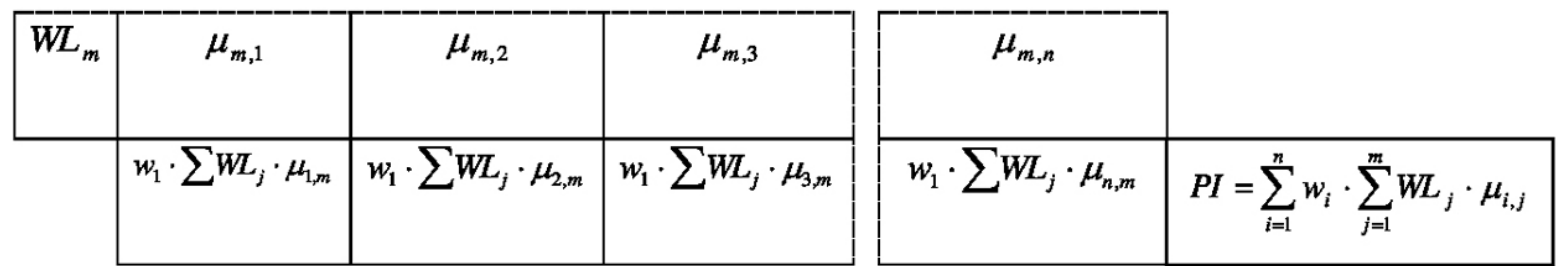

Fig. 3. The graphic algorithm of PI index 
ratios. At fast moistening of soil aggregates the structure becomes damaged by the air closed in small pores. The influence of moisture changes on physical properties is the strongest in the soils with high content of mineral and organic colloids [Bolt and Koenigs 1972]. $\mathrm{pH}$ vales measured in water ranged from 6.15 to 6.86 , whereas measured in $1 \mathrm{n} \mathrm{KCl}$ from 6.24 to 7.12 . The most advantageous for a majority of crops is $\mathrm{pH}$ from weakly acid to neutral [Mocek 2015]. Electrolytic conductivity did not exceed the values regarded as limit values for non-irrigated soils, i.e. $1.0 \mathrm{mS} \cdot \mathrm{cm}^{-1}$ [Nowosielski 1974 ] and according to Jeckson [FAO 2006] classification corresponded to non-saline soils. Determined physicochemical properties do not indicate chemical degradation of soils. Organic matter content ranged from 3.56 to $5.76 \%$. Humus content in the $0-20 \mathrm{~cm}$ horizon of brown soils is between 1.5 and $2.5 \%$ [Zawadzki 1999]. Organic matter contents noted in the investigated area exceed the values above, therefore in case of potential reclamation of this terrain, removal of the humus horizon should be considered. Saturated conductivity coefficients determined by laboratory methods ranged from 0.000151 to $0.02350 \mathrm{~m} \cdot \mathrm{d}^{-1}$. The highest values were noted for loamy sands. Value of saturated conductivity coefficients plays a very important role in the process of hydrological soil degradation in the mining damage areas [Klatka et al. 2015]. Obtained results of an average level of $0.005525 \mathrm{~m} \cdot \mathrm{d}^{-1}$, together with the soil granulometric composition indicate the studied soils susceptibility to hydrological degradation.

Determined values of the researched soils productivity index were on average 0.59 , fluctuating from 0.54 for opening I to 0.64 for opening II. Approximate results were obtained for the area under the influence of mining operations conducted on the upper layer at "Szczygłowice" hard coal mine in Knurów [Klatka 2002]. According to Zhengi $\mathrm{Hu}$ et al. [1992], the maximum value of productivity index (PI) may be 1.0. Values $\mathrm{PI} \leq 0.5$ evidence a strong soil degradation and indicate the need for undertaking urgent reclamation measures. On the other hand, PI values $>0.8$ indicate a slight intensity of degradation processes. Therefore, determined PI value characterizes the studied area as the terrain with poor conditions for agricultural production. The main reason for low PI values is unfavourable change of the soil properties caused by the raising of groundwater table in the investigated area and progressive hydrological degradation. Among the other elements decisive for PI index value one should mention the soil material (sandy loams and loamy sands) occurring in the horizons of the studied soil profiles. The material is characterised by a faulty water regime. Kiniry et al. [1983] demonstrated a similar effect of water content in loamy soils, $\mathrm{pH}$ and volumetric density on productivity index. Thompson et al. [1987] determined the soil productivity index on two hard coal post-mining sites in the US. Their analysis comprised the soil compactness, volumetric density and depth of plant root zones. Obtained results were correlated with maize yields and a strong relationship was revealed between PI indices and yields. Rodrigue and Burger [2004] conducted research on the productivity index of forest soils in the post-mining areas in the eastern and mid-western coal basins in the US. The authors identified main properties of soils influencing the index values, including among others: soil profile saturation with water, content of readily available water, total porosity and electrolytic conductivity. All Authors indicate that the soil productivity index method may be used to assess the needs but also to evaluate the effectiveness of reclamation treatment. In the conditions of Poland, approximate results were obtained for the terrain under the influence of mining operations in Szczygłowice [Klatka 2002]. Currently, water-logged meadows and pastures in this area, which are the property of individual famers, are characterised by a low level of agrotechnological measures, which undoubtedly affects their quality and agricultural suitability. If no agrotechnological measures are conducted in future, we have to recon with increasing wasteland area and successively declining productivity index of studied soils. According to Siuta [2007], a majority of soils with various degree of their top layer sanding is water-logged in the springtime and excessively fossilized in summertime. During the periods of the highest waterlogging of these soils, plants have no conditions for proper vegetation. The most efficient way to counteract waterlogging seems conservation of the existing or construction of a new irrigation systems.

\section{CONCLUSIONS}

The investigated area is under intense influence of underground operations of hard coal extraction. Geomechanical surface transformations 
(subsidence), intensified over time, led to a formation of a landlocked subsidence depression, waterlogged area in the central part of the terrain and global raise of the groundwater table. All these factors cause a hydrological degradation of soils.

Analysis of both field and laboratory tests shows that soil material revealing a high susceptibility to hydrological degradation processes prevails in the discussed area. Beside the mining operations, the size of this form of degradation has been undoubtedly affected by a change of soil properties. The soil physicochemical properties did not point to the symptoms of soil damage due to acidification, alkalinisation or salinity.

Productivity indices determined for the studied soils classify the discussed area as a terrain with poor conditions for agricultural production and evidence the necessity to undertake reclamation treatment. Low values of PI index are mainly affected by the changes of primary soil properties due to degradation processes intensifying over time. Obtained results allow to state that the applied method is not only a quantitative and complex one for the assessment of degraded soil quality, but may be also applied for the estimation of reclamation needs, particularly in post-mining areas. However, the method does not take into consideration current soil fertility and its nutrient status, which make impossible comparing the obtained results with the soil quality classification.

\section{REFERENCES}

1. Assouline S., Tavares-Filh O., Tessier D. 1997. Effect of compaction on soil physical and hydraulic properties. Exp. results and modeling. Soil Sei. Soc Am. J. 61, 2, 390-398.

2. Baranowski R. 1980. Wpływ gęstości gleby na jej właściwości agrofizyczne roczniki gleboznawcze. (Soil bulk density effect on agrophysical properties of soil) [In Polish]. Roczniki Gleboznawcze, XXXI, 2, 15-31.

3. Baver L., Gardner W., Gardner R.W. 1972. Soil Physics. 4 Ed-New York 1972. Wiley 8 Nlb 2, 498.

4. Bolt G. H., Koenigs F. F. R. 1972. Physical and chemical aspects of the stability of soil aggregates. Mededel. Fakult. Landbouwwetenschappen, State University, Ghent, Belgium, 37(3).

5. Doll E.C., Wollenhaupt N.C., Halvorson G.A., Schroeder S.A. 1984. Planning and evaluating cropland reclamation after strip mining in North Dakota. Miner. Environ. 6, 121-126.
6. FAO. 2006 World reference base for soil resources. A framework for international classification, correlation and communication. World Soil Resources Reports No. 103. Roma.128.

7. Kaszowska O. 2007. Wpływ podziemnej eksploatacji górniczej na powierzchnię terenu. (Impact of underground mining on surface of terrain) [in Polish]. Problemy Ekologii, 11(1), 52-57.

8. Kiniry L.N., Scivner C.L. Keener. M.E. 1983. Soil Productivity Index Based Upon Predicted Water Depletion and Root Growth. University of Missouri. Columbia College of Agricultural Experiment Station Director. USA. Research Bulletin, 1051.

9. Klatka S., Malec M, Ryczek M, Kruk E. 2016. Use of the synthetic index of agricultural environment quality for evaluation of soils degraded as a result of stone coal exploitation. Ochrona Środowiska i Zasobów Naturalnych. Environmental Protection and Natural Resources, 27, 4(70), 12-16.

10. Klatka S. 2002. Indeks produktywności gleb zdegradowanych w wyniku działalności eksploatacyjnej Kopalni Węgla Kamiennego „Szczygłowice”. (Soil productivity index of the soils degraded as a result of stone coal exploitation KWK "Szczygłowice") (in Polish).

11. Roczniki Akademii Rolniczej w Poznaniu CCCXLII. Melioracje i Inżynieria Środowiska, 201-209.

12. Klatka S., Malec M., Ryczek M., Boroń K., 2015. Wpływ działalności eksploatacyjnej kopalni węgla kamiennego „Ruch Borynia” na gospodarkę wodną wybranych gleb obszaru górniczego. Acta Scientiarum Polonorum, Formatio Circumiectus, 14(1), 115-123.

13. Klatka S., Malec M., Ryczek M. Analysis of Spatial Variability of Selected Soil Properties in the Hard Coal Post-Mining Area. Journal of Ecological Engineering, 20(3), 185-193.

14. Mocek A., Drzymała S., Maszner P. 1997. Geneza, analiza i klasyfikacja gleb. (Genesis analysis and classification of soils). Wydawnictwo AR Poznań (in Polish).

15. Mocek A. 2015. Gleboznawstwo (Soil science). PWN Warszawa (in Polish).

16. Neill L.L. 1979. An evaluation of soil productivity based on root growth and water depletion. M.S. Thesis. Univ. of Missouri.

17. Nowosielski O. 1974. Metody oznaczania potrzeb nawożenia (Methods for determining fertilization). PWRiL Warszawa (in Polish).

18. Oleksynowa K., Tokaj J., Jakubiec J. 1987, Przewodnik do ćwiczeń z gleboznawstwa i geologii (Guide to exercises in soil science and geology). AR w Krakowie (in Polish).

19. Polskie Towarzystwo Gleboznawcze, 2011. Systematyka Gleb Polski (Polish soil classification). Rocz. Glebozn., LXII (3), 193 (in Polish). 
20. PN-R-04033 1998. Gleby i utwory mineralne. (Soil and mineral soil materials). Polski Komitet Normalizacyjny Warszawa (in Polish).

21. Porter K.N., Carter F.S., Doll E.C. 1988. Physical properties of constructed and uncostructed soils. Soil Sci. Soc. Am. J., 52. 1435-1438.

22. Reith A, Charles C. 1982. Factors related to reclamation success on gradem spoi land topdressed surface at two coal mine in New Mexico. Symposium of Surface Mining. Universytet of Kentacky, Lexington, 5-10.

23. Rodrigue J.A., Burger J.A. 2004. Forest Soil Productivity of Mined Land in the Midwestern and Eastern Coalfield Regions. Soil Science Society of America Journal Abstract. Division s-4, Soil fertility \& plant nutrition, 68(3), 833-844.

24. Rosik-Dulewska Cz., Wrona A., Gronet R., 1999. Przekształcenia użytkowania gruntów na obszarach górniczych KWK.,Knurów” i KWK, ,Szczygłowice” (Changes in land use on mining areas of 'Knurów' and 'Szczygłowice' coal mines). Archiwum Ochrony Środowiska, 25(4), 89-117 (in Polish).

25. Ryczek M., Kruk E., Malec M., Klatka S. 2017. Comparison of pedotransfer functions for determination of saturated hydraulic conductivity coefficient. Environmental Protection and Natural Resources, 28, 1(71), 25-30.

26. Siuta J. 2007. Ekologiczna rola regulacji stosunków wodnych w glebie (Ecological magnitude of the regulation of relation between water and air in soil). Inżynieria Ekologiczna, 18, 19-22 (in Polish).

27. Thompson, P.J., I.J. Jansen and C.L. Hooks. 1987. Penetrometer resistance and bulk density as parameters for predicting root system performance in mine soils. Soil. Sci. Soc. Am. J., 51, 1288-1293.

28. Zając E., Zarzycki J. 2013. Wpływ aktywności termicznej zwałowiska odpadów węgla kamiennego na rozwój roślinności (The Effect of Thermal Activity of Colliery Waste Heap on Vegetation Development). Annual Set The Environment Protection, 15 (2), 1862-1880 (in Polish).

29. Zawadzki, S. 1999. Gleboznawstwo (Soil science). PWRiL Warszawa (in Polish).

30. Zenqi Hu, Caudle R.D., Xhong S.K. 1992. Evaluation of farmland reclamation effectiveness based on reclaimed mine soil properties, International Journal of Surface Mining, Reclamation and Environment, 6(3), 129-135. 